\title{
China's SOE Executives: Drivers of or Obstacles to Reform?
}

\author{
KJELD ERIK BRØDSGAARD, PAUL HUBBARD, GUILONG CAI \\ AND LINLIN ZHANG
}

\begin{abstract}
Drawing on a database tracking the career of 1,250 top Chinese executives from 1,084 publicly-listed state-owned enterprises (SOEs), this article analyzes differences in career incentives for subsidiaries controlled by the central government compared to those controlled by local governments. It also considers the differences for executives in listed companies close to the parent group compared to those that are heads in distant subsidiaries. We find that in both SOEs and their publicly listed subsidiaries, administrative experience or political connections appear to increase the likelihood of promotion. However, in the case of central SOE subsidiaries, leaders are more likely to be promoted based on financial performance. For both central and local 'direct' SOE groups age is a significant negative factor for promotion, whereas tenure is a significant positive factor.
\end{abstract}

Keywords: China, state-owned enterprises, Chinese business executives, career incentives, economic performance, iron triangle

\section{Introduction $^{1}$}

Prior to China's economic reform and opening up, the industrial economy was almost entirely state-owned. But despite the emergence of a dynamic private sector (Naughton 1996; Lardy 2014), state-owned enterprises (SOEs) have not withered away. The market now officially plays a 'decisive' role in resource allocation, but public ownership remains the ideological foundation of the Chinese economy, according to the Chinese Communist Party Central Committee's 2013 Decision on Major Issues Concerning Comprehensively Deepening Reforms (Communist Party of China 2013). ${ }^{2}$ China's largest companies, which dominate key economic sectors, are SOEs (Hubbard \& Williams 2016). SOEs are also the largest Chinese investors abroad. ${ }^{3}$ 
On the surface many of these companies have adopted Anglo-American corporate governance forms and have publicly-listed subsidiaries. However, their controlling shareholder is the Chinese government, and the Communist Party of China (CPC) plays a key role in choosing their executives. Who are the leaders of these companies? How are they appointed? What do their career paths look like, and what are their career incentives? Do they behave like business leaders, or are they more like Party-state bureaucrats?

This article draws on a database tracking the careers of 1250 top executives (CEO, board chairman and Party Secretary) from 1084 publicly-listed SOEs from 2003 to 2012. It considers differences in career incentives for subsidiaries of SOEs controlled by the central government (yang qi) compared to those controlled by local governments ( $g u o q i$ ), as well as between listed SOEs that are close to the top of corporate groups and those that are distant subsidiaries.

\section{The Iron Triangle: Party, State and Business}

SOEs are no longer mere 'workshops' of the China's state planning apparatus. By and large they have adopted corporate forms inspired by Anglo-American corporate governance. Many have partially-privatized subsidiaries listed on sharemarkets in China and abroad. But formal governance structures do not necessarily translate to the substantive profit-seeking behaviour expected of privately-owned enterprises. Their controlling shareholder (the Chinese State) has myriad economic and political objectives, and their human resources function for top management is managed by the CPC. This creates an 'iron triangle' of mutually supportive relationships between the state, Party, and business (Brødsgaard 2012). These relationships are structured by the Party and form the core of the Chinese power system. If the 'iron triangle' is broken, the system will change, possibly resulting in the collapse of CPC domination.

The state, Party and business are at the corners of a triangle, but the boundaries between them are not strictly defined. Different formal relationships between state and business at various levels can resemble a matrix muddle.

An overview of the essential elements and relations between ownership and governance in state and private business is provided in Figure 2 , which distinguishes five discreet categories ranging from purely state, to state-owned enterprises, to state-controlled enterprises and private- 
controlled mixed capital and purely private investors. Within these we can identify different types of enterprises or corporate forms that carry out business activity. Party organizations run parallel to these at all levels, although the role of the Party varies.

FIGURE 1. The Chinese Iron Triangle: Relationships between the Party, State and Business

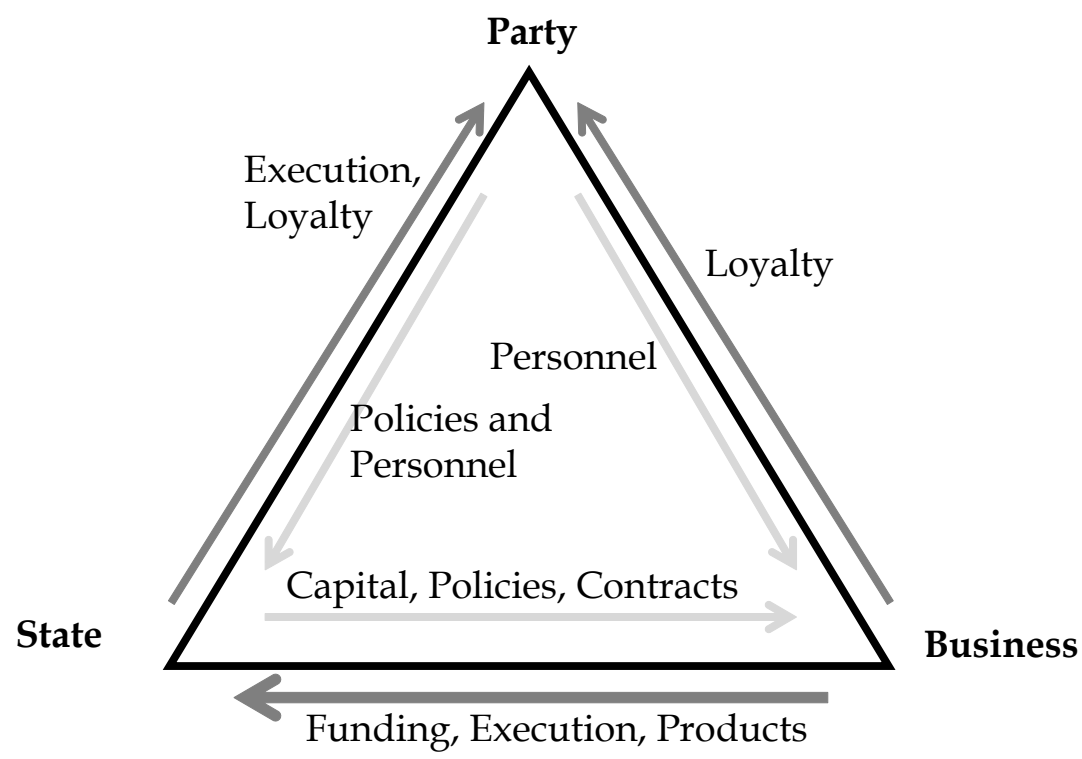

\section{State Organs}

The State Council of the People's Republic of China is the highest executive organ of the Chinese central government. It oversees all state ministries, commissions and administrations. Since 2003 the State Owned Assets Supervision and Administration Commission (SASAC) of the State Council has been responsible for managing central SOEs. Certain sectors, such as finance, tobacco and media, are owned and controlled by other state ministries. The Chinese government also controls other assets through its sovereign wealth funds and public pension funds (Cummine 2015). ${ }^{4}$

China's provinces, autonomous regions and provincial-level municipalities (Beijing, Chongqing, Shanghai and Tianjin) are subordinate to the central government. Each of these provincial-level governments has its own SASAC, which oversees provincial SOEs. Provinces and municipalities oversee hundreds of lower-ranked counties and other administrative districts with their own SASACs, which in turn oversee thousands of 'local' SOEs. 
FIGURE 2. Ownership and governance of state-owned and state controlled enterprises

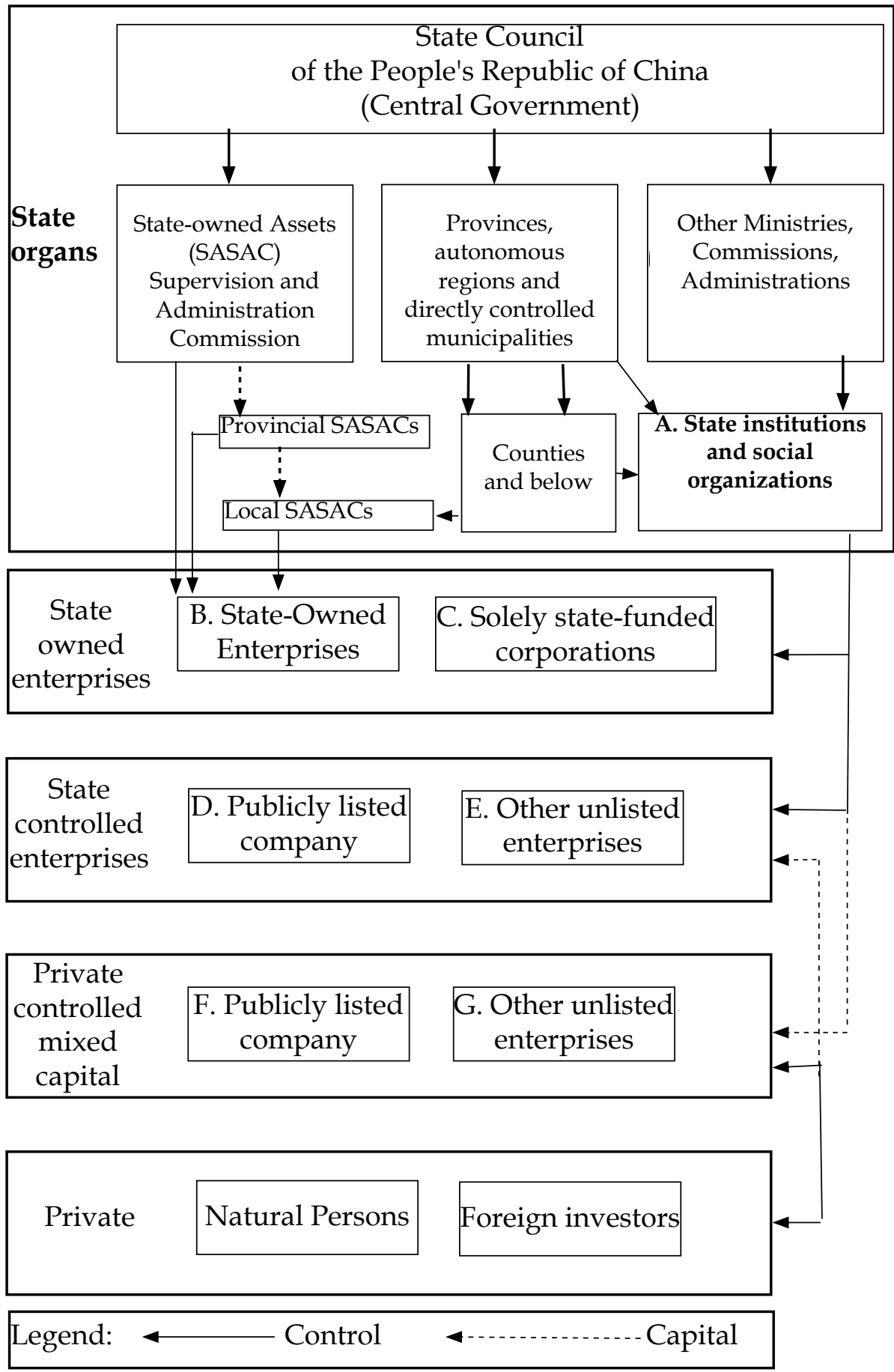


Public education and social welfare functions are provided directly by state institutions and organisations at central, provincial and local levels (box A in Figure 2).

\section{The Party's Role within the State}

The Party completely dominates state organs. It sets the policy direction for state bodies which the state in turn executes. The Party not only makes key personnel appointments to the state, but also ensures that key state appointments, such as to the State Council and provincial leadership, overlap with Party organs up to the highest level. Political relationships are therefore linked to promotion prospects for Chinese state officials.

A general literature addressing the official promotions can be divided into three schools. One school argues that political connectedness and patronage relationships determine the possibility of promotion (Shih, Adolph \& Liu 2012; Chen 2006). Another school holds that economic performance increases the likelihood of promotion (Li \& Zhou 2005; Landry 2008; Yao 2016). A third contends that economic performance matters more as a factor for promotion at lower levels of government, whereas political connectedness matters more at the central level (Choi 2012; Landry, Lü \& Duan 2014). ${ }^{5}$

\section{State-owned Enterprises}

In the classical socialist econo0my, there was no distinction between the workshop (production unit) and the state itself, and so pre-reform stateowned enterprises can be thought of as an integrated part of the state (Kornai 1992). With the reform and marketization of the Chinese economy, most productive sectors of the economy were spun-off from the state.

Beginning with experimentation in October 1978, separate enterprises were created that were distinct from - though still highly dependent on - the state ( $\mathrm{Wu} 2005: 145)$. This could be at a small scale, but sometimes it involved the wholesale conversion of entire government ministries. Most state-owned enterprises today can therefore be traced back to bureaux within ministries.

Some were converted wholesale from entire ministries. China's three oil giants were formed to take over the assets of the Ministry of Petroleum - China National Offshore Oil Corporation (CNOOC) in 1982, China National Petroleum Corporation (Sinopec) in 1983 and China National Petroleum and Natural Gas Corporation (CNPC) in 
1988. These new corporations not only took over the ministry's assets and enterprise functions, but replaced its administrative functions too (Brødsgaard 2012; Zhang 2004).

Today, state-owned enterprises are overseen by state organs, but are no longer formally part of the state. Technically, a SOE is a wholly-state owned, non-corporate entity registered according to Regulation of the People's Republic of China on the Registration of Enterprises and Corporations (box B). State agencies and SOEs can also hold shares in 'solely state-funded limited liability corporations (LLCs)'. LLCs are registered according to the Regulations for the Administration of Company Registration and have between two and 50 shareholders (box C). ${ }^{6}$

The largest and most important SOEs, the so-called central enterprises, are managed by the SASAC of the State Council (Brødsgaard 2012). There are now 106 of these companies, which are also known as China's national champions as they include China's largest and most important companies (Hubbard \& Williams 2016) including in energy, resources and public utilities (Hubbard 2016a). Provincial and local governments' SASACs oversee thousands of local SOEs that are small and typically involved in more competitive sectors of the economy, but these can still be relatively large and important within their province.

Central SOE leaders are subject to three-year performance contracts from the central SASAC. Performance standards relate to financial indicators of the firm, including growth in revenue and profitability. SOE leaders are graded between A to E based on these standards and receive corresponding financial bonuses.

\section{Party Role within State-owned Enterprises}

State-owned enterprises all have a Party Committee with a clear mandate from the Party Constitution. A party organization in a state owned enterprise

guarantees and oversees the implementation of the principles and policies of the Party and the state in [the]... enterprise and backs the meeting of shareholders, board of directors, board of supervisors and manager (factory director) in the exercise of their functions and powers according to law (Xinhua 2013). ${ }^{7}$

Alongside this formal arrangement, there is a convention that the Chairman of the Board of Directors (where there is one) or the general manager concurrently holds the position of Secretary of the SOE's Party Committee. As the Chairman of the Board is normally regarded as the top person (diyi 
bashou) in the company, this rule consolidates the Party's dominant role. Directives on SOE reform from September 2015 stress the leading role of the Party in SOE governance through this arrangement, even though the thrust of the reform is to insulate enterprise decisions and governance from formal state control (Communist Party of China 2015). ${ }^{8}$

There have been several attempts to abolish administrative ranking for central SOEs. As early as 2000, the Party passed a plan for deepening the reform of cadre personnel work, stipulating that administrative ranking for enterprises should be abolished (Zhonggong zhongyang bangongting). ${ }^{9}$ Subsequently, the issue has resurfaced frequently but SOE leaders have been opposed to these attempts and still consider themselves to hold vice-ministerial rank (Suo 2014). ${ }^{10}$ In short, administrative rank for SOE executives has been formally abolished, but in practice it still exists.

The leaders of the 53 most important central SOEs are directly appointed by the Party's Central Organization Department according to the nomenklatura system which handles appointments at or above vice-ministerial level (Brødsgaard 2012). They therefore enjoy high political status and social influence in the Chinese rank-stratified political order. A very small number of SOE heads enjoy even higher status in a Party capacity as members or alternate members of the Party's Central Committee. Other central SOE leaders are appointed by SASAC, subject to the central organization department's veto. They are ranked at departmental level (ju/si or ting).

Provincial SOE heads are ranked at a much lower level (equivalent to that of a deputy mayor of a prefectural level city, such as Suzhou). Heads of county SOEs are ranked even lower. They are responsible to the SASAC of the provincial government (or a branch of SASAC at county-level), and appointments are controlled by the local party apparatus rather than the central Government.

In an Anglo-American corporate model, members of a company board have a fiduciary duty to act in the interests of the company. A failure to do so may be punished by a general meeting of shareholders, which can ultimately determine the fate of the company leadership. By contrast, while the leaders of SOEs do have an interest in the financial performance of the SOE (including the performance pay from SASAC), their longer term career prospects are embedded in Party structures. If their personal ambitions go beyond running one of China's largest companies, then they need to obtain higher political rank by shifting career track to a government or Party position. This leaves open the 
chance of attaining ministerial rank and postponing retirement by five years. This career shift is determined by the central Party, rather than the SOE or its nominal state owner.

There are three post-CEO pathways. One is lateral transfer from CEO or Chairman of a SASAC company to a Party or government position in a province or municipality. Individuals following this pathway will normally be transferred to a position as vice governor or deputy provincial or municipal Party secretary. Another pathway is lateral transfer from executive leadership of a central enterprise to a government or Party position at the central level, at vice-ministerial level. Although, lateral transfer from one vice-ministerial position in a company to a similar ranked position in government is not strictly a promotion, we regard it as such because the transfer opens the door for further career advancement along the civil servant track. A less common third pathway is direct promotion to a ministerial level within the central government.

The career incentives of SOE leaders are yet to be studied in Englishlanguage academic literature. The leading study in Chinese, Yang, Wang and Nie (2013), considers factors affecting the career movements of 189 leaders of central SOEs between 2008-2011. They find that increased economic performance (measured by growth of operating revenue) increases the chance of promotion. They also find that leaders who are members of the Party's Central Committee, and those that hold a PhD degree, have higher promotion prospects. They conclude that central SOE heads are 'quasi-government officials' rather than professional managers because their SASAC-determined performance pay has no significant link to promotion.

The career paths of executives in SOE subsidiaries are also yet to be systematically researched. But it is important since these large corporate structures can provide an environment for aspiring SOE leaders to work their way up from lower-level subsidiaries. Most leaders within central SOE conglomerates advance through their own company on the basis of what could be called a single-group career track, where they typically start their career from a subsidiary and then move to the parent company. Another career path is a multi-group career track where business executives have work experience in SOEs in the same industry.

There are ten current leaders of central SASAC SOEs whom we observe having previous positions in listed lower-level subsidiaries. One of these, Xu Lejiang, is Chairman and Party Secretary of Baosteel Group Corporation and the head of its listed subsidiary Baoshan Iron \& Steel Co., Ltd., and an alternate member of the 17th and 18th Central Com- 
mittee. Others became leaders in the SASAC parent after experience in listed subsidiaries within the same industry, if not the same SOE:

- Ma Zehua, a former leader in the Shanghai-listed Cosco Shipping Company Limited, became Chairman of the Board and Party Secretary of the China Ocean Shipping (Group) Company after July 2013. $\mathrm{Xu}$ Lirong, also a prior leader in the Shanghai-listed subsidiary, took over Mr Ma's roles in the parent in January 2016. ${ }^{11}$

- The General Manager and Deputy Party Secretary of China Huaneng Group, Cao Peixi, was previously Chairman of Huadian Power International Corporation Limited. He is also a delegate to the 16th, 17th and 18th CPC National Congress, and a member of the 18th Central Commission for Discipline Inspection.

- Huang Yongda was a leader in Shanghai-listed Huaneng Power International, INC. (a subsidiary of China Huaneng Group) before becoming Party Secretary and General Manager at Huaneng Group.

- Li Qingkui, currently Chairman and Party Secretary China Huadian Corporation (CHD), was previously a leader in Shenzhen-listed Guodian Changyuan Electric Power Company.

- Chen Esheng is Chairman and Party Secretary of Sinolight Corporation and was previously a leader at its Shenzhen-listed subsidiary, China Haisum Engineering Co., Ltd.

- Fu Yuning is Chairman and Party Secretary of China Resources (Huirun Group) and was previously Chairman of Shenzhen-Listed China International Marine Containers (Group) Co.

- Wen Gang is General Manager at China North Industries Group Corporation (NORINCO) and was previously a top executive at Shenzhen-listed SNC OPTO Electronic Co Ltd, an LED exporter.

- Rui Xiaowu was Chairman and Party Secretary of China Electronics Corporation and was previously a leader at Shenzhen-listed NavInfo - at NORINCO.

\section{State-Controlled Enterprises}

Many of the companies commonly referred to as SOEs are not strictly state-owned enterprises at all by the above definitions. They can be more accurately described as 'state-holding' or 'state-controlled' enterprises. These are not SOEs, but separate corporate entities, joint ventures and partnerships in which an SOE or another state-controlled enterprise has the largest capital share. This can include enterprises that are wholly- 
owned or majority-owned by SOEs, or even minority-owned provided that there is no larger non-state shareholder.

Table 1 shows basic statistics for SOEs in China's industrial sectors. ${ }^{12}$ These show the breakdown of 9,535 'first tier' SOEs in the industrial sector between central SASAC, other ministries and local governments in 2009. Beyond this are 15,861 direct subsidiaries (second tier state-controlled enterprises) and subsidiaries of these subsidiaries (third tier subsidiaries). Central SOEs are often sprawling corporate conglomerates. In total, central industrial SOEs and their second- and third-tier subsidiaries employ 7.7 million workers. By contrast, local SOEs employ almost 10 million workers, but have on average only one or two subsidiaries and are also much smaller in terms of assets.

TABLE 1. Industrial SOEs and their subsidiaries, 2009

\begin{tabular}{|r|r|r|r|r|}
\hline & First tier & To third Tier & Employees & $\begin{array}{c}\text { End of year state } \\
\text { assets (million RMB) }\end{array}$ \\
\hline Industrial SOES & $\mathbf{1 0 1 2 5}$ & $\mathbf{3 6 6 1 8}$ & $\mathbf{1 8 , 4 4 5 , 0 0 0}$ & $\mathbf{7 , 3 4 0 , 9 8 0}$ \\
\hline $\begin{array}{r}\text { of which, Central } \\
\text { Government }\end{array}$ & 590 & 11222 & $8,464,000$ & $5,057,120$ \\
\hline Central SASAC & 56 & 10442 & $7,734,000$ & $4,258,180$ \\
\hline Other Ministries & 534 & 780 & 730,000 & 798,990 \\
\hline $\begin{array}{r}\text { of which, Local } \\
\text { Government }\end{array}$ & 9535 & 25396 & $9,981,000$ & $2,283,860$ \\
\hline
\end{tabular}

Source: SASAC Yearbook 2010

Some of these SOE subsidiaries are shareholding corporations that are publicly listed on Chinese or international sharemarkets (box D). This makes them 'partially privatised' through the involvement of private Chinese and foreign investors. Their shareholders can include other SOEs, their subsidiaries, as well as China's largely state-owned financial institutions. One motivation is to attract external capital, another is an attempt to improve economic performance through independent external oversight of profit-seeking investors.

Public listing of large SOE subsidiaries was a policy initiative from the late 1990s. For example, a decade after being created from the state oil ministry in 1988, CNPC's core assets in extraction, refining, chemical and retailing were restructured into a subsidiary called 'PetroChina' which was then listed on Hong Kong and New York Stock Exchanges in March 2000 (Wu 2005: 156-157). The wholly-state-owned central SOE retains an 87 per cent ownership share in this subsidiary (see Figure 3).

SOE subsidiaries, and even their subsidiary companies, can also be listed. For example, Tongrentang, a traditional Chinese medicine com- 
FIGURE 3. A directly-controlled, central SOE subsidiary

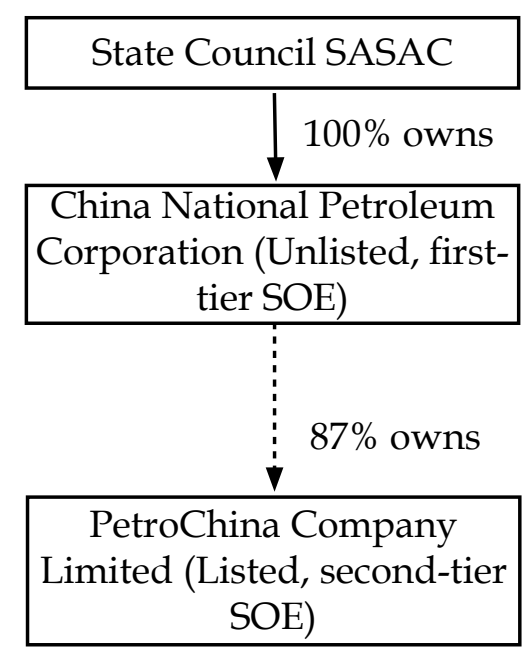

pany, was founded in the 1669 during the Qing dynasty. The China Beijing Tongrentang Group is today a wholly-owned subsidiary of a capital management company that sits directly under Beijing municipality SASAC. The Tongrentang Group owns a majority stake in Beijing Tongrentang Shareholding Ltd which is listed on the Shanghai Stock Exchange (Figure 4).

FIGURE 4. An indirectly-controlled, local SOE subsidiary

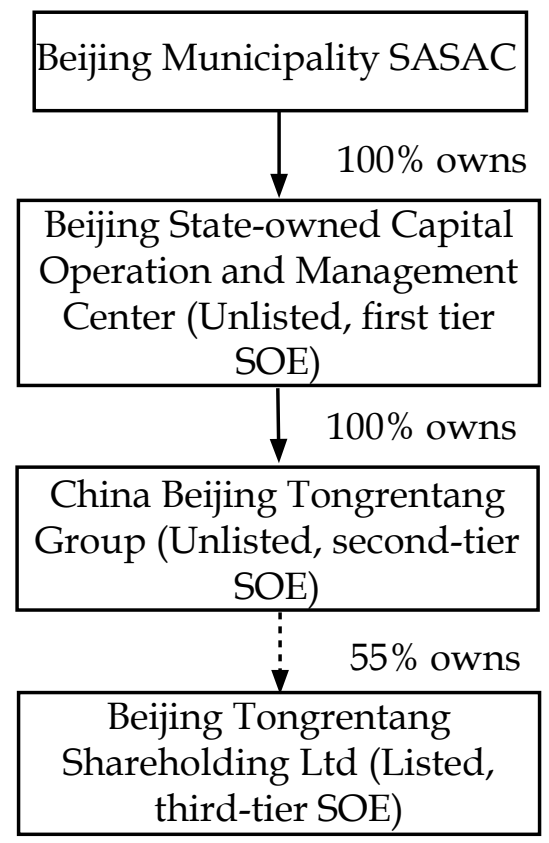


These are simplified, stylized examples. Tracing ownership of listed Chinese companies takes hours of painstaking work for each company. Central SOE China National Chemical Corporation (ChinaChem) has at least nine listed subsidiaries (including 17 interspersed companies and a joint venture with Guangzhou City SASAC) (Rooker 2016a). ${ }^{13}$ Bright Foods, which is ultimately owned by Shanghai SASAC, has direct and indirect interests in five listed subsidiaries (Rooker 2016b). ${ }^{14}$ The largest central SOE conglomerates have an average of 185 second and third tier subsidiaries.

A condition of listing on a stock exchange is the need to report detailed corporate information to inform current and potential shareholders. This data is readily used for research, including this article. As of May 2016, Google Scholar lists 51 research report results for a search on 'publicly listed SOEs' relating to China. However, data on 'listed SOEs' does not reflect what might go on the balance sheet of the parent SOE and its other unlisted subsidiaries; as such, care needs to be taken when drawing inferences from publicly-listed SOE subsidiaries to the state sector as a whole.

Outside listed SOE subsidiaries for which ownership information is on the public record, there are thousands of joint ventures, limited liability companies, partnerships and shareholding corporations which may have any degree of state ownership. All large scale industrial enterprises provide information through annual statistical returns to the National Bureau of Statistics that are widely used by researchers (Brandt, Van Biesebroeck \& Zhang 2014). These data can identify state-controlled enterprises, and the level at which the company is supervised, but does not identify the controlling owner.

One of the ways that a state-owned enterprise (or its subsidiary) has to control its subsidiary is to ensure overlapping management positions between the state-owned parent and the publicly-listed subsidiary. A survey of 109 listed companies cited by Fu (2013), found that 80 per cent of chairmen in central listed SOE's subsidiaries are senior executives of the unlisted parent. In the following, we will present empirical evidence for factors influencing the careers of leaders of listed SOEsubsidiaries.

\section{Private-controlled Mixed Capital}

The state, state-owned enterprises and state-controlled enterprises can also contribute capital to private-controlled enterprises. These could be enterprises that were previously state-owned enterprises but have 
been partially-privatized to the extent that that the largest shareholder is now private. These can be through publicly listed companies (box F), or through all kinds of unlisted public-private partnerships, joint ventures and other mixed arrangements with private domestic or foreign investors (box G).

Finally, there are truly private enterprises with which the state has no ownership relationship whatsoever. Many of the unlisted privatecontrolled companies also fall into this category, but they cannot be definitively identified from the available statistics, although some enterprises are registered as solely private- or foreign- funded, or are self-employed private individuals.

\section{Party Role within Private Enterprises}

The Party has a role in mixed ownership and fully private enterprises. The Companies Law of the People's Republic of China makes it explicit that 'grass roots organizations of the Communist Party' (including Party committees) are allowed to carry out their activities in companies (even foreign companies) in accordance with the Party Constitution. Reportedly 'all 210,000 large private companies' now have Party Committees and have recruited more than 3.5 million workers (Xinhua 2012) ${ }^{15} \mathrm{Nev}$ ertheless, their mandate is weaker than in state-owned enterprises. In a private enterprise, the Party Committee is meant to 'guide and oversee the enterprise in observing (state) laws and regulations.' It comes with a pro-business rider that the Committee 'stimulates the healthy development of the enterprise' (Hawes 2007). ${ }^{16}$

Thus even complete independence from state ownership does not rule out business-Party links. However, although the Party has had individual private entrepreneurs as members since 2002, less than 1 per cent of individually owned enterprises (getihu) have Party Committees (Xinhua 2012).

\section{Career Incentives for Leaders of Listed SOE Subsidiaries}

We have already noted previous studies of career incentives for state officials, and heads of central state-owned enterprises. We have noted that SOEs provide a career track to official positions. But who are the leaders of these companies? How are they appointed, what do their career paths look like, and what are their career incentives? Do they behave like business leaders, or are they more like Party-state bureau- 
crats? The answers to these questions not only inform our understanding of the 'iron triangle', but also have implications for the efficiency of state capital. If state assets are managed by professional businessmen, who are rewarded for financial performance and are at arms' length from the state, then SOE company performance matches that of professionally-managed private companies. By contrast, if state assets are managed by 'quasi-officials', then the firm's financial performance is more likely to be impaired by the 'soft budget constraint syndrome' and policy burdens (Kornai, Maskin \& Roland 2003; Lin \& Tan 1999) that impair company performance.

We investigate this issue using a database of 1,241 executive movements between 2003 and $2012{ }^{17}$ for leaders in state-controlled companies listed on the Shanghai or Shenzhen Stock Exchange and quoted in RMB (that is 'A' shares). Detailed financial information of listed companies was obtained from GTA Information Technology. Biographical information was hand-collected from annual reports, company announcements and other publicly-available official company documents. Supplementary information was taken from the web portal Sina Finance (Xinlang Caijing), corporate websites and SASAC websites. A detailed description of this dataset and the preliminary findings have been published in Chinese (Zhang, Liu \& Cai 2015).

Listed companies are classified according to whether the ultimate owner is administered by the central government, a province or a county. We divide listed companies into two groups: those that are directly administered by the state or by an SOE (that is, first- and second-tier companies) and those that are more than two steps removed from the state parent (third-tier down to ninth-tier in our sample). We consider that the further down the chain of listed subsidiaries, the more the leadership is to be insulated from political demands (Fan, Wong \& Zhang 2013; Zhongming 2010). ${ }^{18}$ Table 2 shows the distribution of executive movements according to the classification of the listed SOE subsidiary.

Firstly, we consider the question of where leaders of listed SOE subsidiaries have career tracks that go beyond strictly business, and include outside political or work connections. Yang et al (2013) focused on Central Committee membership as an indicator of political connections for central SOE heads. Because we are considering SOE subsidiaries at central and provincial levels, we need broader measures of connections. In this case, we define a political role as being a representative to the National or a provincial People's Congress, or Committee member of the national or a provincial Political Consultative Conference. We also 
TABLE 2. Executive movements by company type and level

\begin{tabular}{|c|c|c|c|}
\hline & Type & Indirect & Total \\
\hline County & 64 & 216 & 280 \\
\hline$\%$ & 22.86 & 77.14 & 100 \\
\hline Provincial & 161 & 330 & 491 \\
\hline$\%$ & 32.79 & 67.21 & 100 \\
\hline Central & 334 & 136 & 470 \\
\hline$\%$ & 71.06 & 28.94 & 100 \\
\hline Total & 559 & 682 & 1,241 \\
\hline$\%$ & 45.04 & 54.96 & 100 \\
\hline
\end{tabular}

include prior work experience as a government official or in another public enterprise.

Table 3 indicates that more than a third of leaders of listed SOE subsidiaries have this type of experience. The proportion is slightly higher

TABLE 3. Leaders with external political links and administrative experience

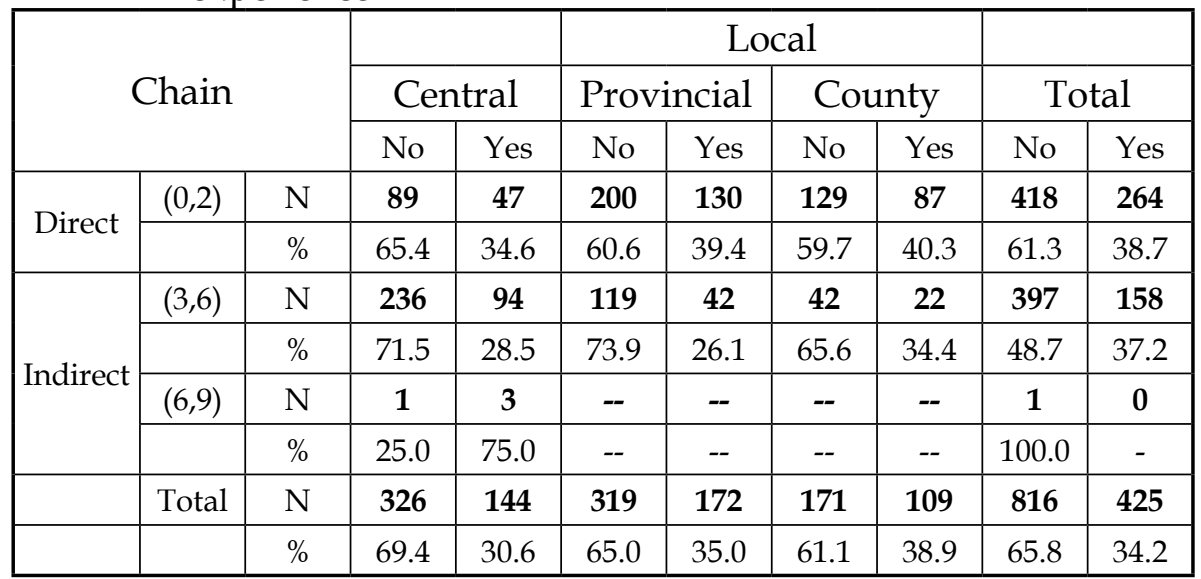

for local SOE subsidiaries. Leaders closer to the top of the subsidiary chain are also more likely to have this experience.

We track leaders each time their position changes, according to six categories:

1) Demotion: movement to a lower level enterprise (including from a parent to a subsidiary), movement from a leadership position to become an ordinary board member or deputy-leader in the same SOE subsidiary, or another SOE subsidiary of the same rank.

2) At level: moving to another SOE subsidiary at the same administra- 
tive level or returning to a previously held position.

3) Promotion: movement to a leadership position in a higher-level enterprise (including from a subsidiary company to a parent, or where the new SOE-subsidiary is clearly of a higher administrative rank), promotion within the same company (for example, from general manager to Chairman of Board), or appointment to a government position.

4) Retirement: due to age, illness, criminal investigation or discipline inspection.

5) Movement to a non-state owned enterprise: to, for example, a private business.

6) Unknown.

Table 4 shows 395 (31.8 per cent) leadership promotions. We note that leaders of 'directly controlled' are slightly less likely to be promoted. Transfer at level occurred 22.8 per cent of the time, and leaders were demoted 22.0 per cent of time. Likelihood of demotion increases for provincial- and county- level SOEs. The rate of retirement due to age or

TABLE 4. Career outcomes for state-controlled listed company leaders

\begin{tabular}{|l|c|c|c|c|c|c|c|c|}
\hline \multicolumn{2}{|c|}{} & \multicolumn{2}{c|}{ Central } & \multicolumn{2}{c|}{ Provincial } & \multicolumn{2}{c|}{ County } & \\
\cline { 2 - 9 } \multicolumn{2}{c|}{} & Direct & Indirect & Direct & Indirect & Direct & Indirect & Total \\
\hline \multirow{2}{*}{ Promotion } & $\mathbf{N}$ & $\mathbf{4 0}$ & $\mathbf{1 2 0}$ & $\mathbf{9 1}$ & $\mathbf{6 2}$ & $\mathbf{6 4}$ & $\mathbf{1 8}$ & $\mathbf{3 9 5}$ \\
\cline { 2 - 9 } & $\%$ & 3.22 & 9.67 & 7.33 & 5 & 5.16 & 1.45 & 31.83 \\
\hline \multirow{2}{*}{ At level } & $\mathbf{N}$ & $\mathbf{4 3}$ & $\mathbf{8 3}$ & $\mathbf{7 9}$ & $\mathbf{3 7}$ & $\mathbf{3 2}$ & $\mathbf{9}$ & $\mathbf{2 8 3}$ \\
\cline { 2 - 9 } & $\%$ & 3.46 & 6.69 & 6.37 & 2.98 & 2.58 & 0.73 & 22.8 \\
\hline \multirow{2}{*}{ Demotion } & $\mathbf{N}$ & $\mathbf{1 9}$ & $\mathbf{6 5}$ & $\mathbf{7 5}$ & $\mathbf{3 4}$ & $\mathbf{6 0}$ & $\mathbf{2 0}$ & $\mathbf{2 7 3}$ \\
\cline { 2 - 9 } & $\%$ & 1.53 & 5.24 & 6.04 & 2.74 & 4.83 & 1.61 & 22 \\
\hline \multirow{2}{*}{$\begin{array}{l}\text { Retirement } \\
\text { or illness }\end{array}$} & $\mathbf{N}$ & $\mathbf{1 9}$ & $\mathbf{2 0}$ & $\mathbf{4 2}$ & $\mathbf{1 0}$ & $\mathbf{1 3}$ & $\mathbf{5}$ & $\mathbf{1 0 9}$ \\
\cline { 2 - 9 } $\begin{array}{l}\text { Private or } \\
\text { NGO }\end{array}$ & $\mathbf{N}$ & $\mathbf{5}$ & $\mathbf{1 4}$ & $\mathbf{1 0}$ & $\mathbf{5}$ & $\mathbf{1 6}$ & $\mathbf{2}$ & $\mathbf{5 2}$ \\
\cline { 2 - 9 } Unknown & $\%$ & 0.4 & 1.13 & 0.81 & 0.4 & 1.29 & 0.16 & 4.19 \\
\cline { 2 - 9 } & $\mathbf{N}$ & $\mathbf{1 0}$ & $\mathbf{3 2}$ & $\mathbf{3 3}$ & $\mathbf{1 3}$ & $\mathbf{3 1}$ & $\mathbf{1 0}$ & $\mathbf{1 2 9}$ \\
\hline \multirow{2}{*}{ Total } & $\mathbf{N}$ & $\mathbf{1 3 6}$ & $\mathbf{3 3 4}$ & $\mathbf{3 3 0}$ & $\mathbf{1 6 1}$ & $\mathbf{2 1 6}$ & $\mathbf{6 4}$ & $\mathbf{1 2 4 1}$ \\
\cline { 2 - 9 } & $\%$ & 10.96 & 26.91 & 26.59 & 12.97 & 17.41 & 5.16 & 100 \\
\hline
\end{tabular}

illness is more than double for directly controlled enterprises compared to indirectly controlled enterprises.

A key finding is that the leader of a listed SOE subsidiary is almost twice as likely to retire as they are to leave the state sector. 7.4 per cent of leaders in directly controlled county-SOE subsidiaries leave for the private sector. Some of the 'unknowns' may belong to this category. 
Table 5 shows that out of the 395 leaders who were promoted, 81 (20.5 per cent) were appointed to government positions. At the central level, only 6.9 per cent of listed central leaders were appointed to government positions during this time, with appointment to government more likely from a second-tier company. These figures may be an underestimate, if progression to the SOE parent is a 'stepping stone' to a government position. Transfer to government positions are much more likely at local levels, particularly amongst county SOE subsidiaries, in which almost half of leader promotions were to government positions.

TABLE 5. Promotion to government positions

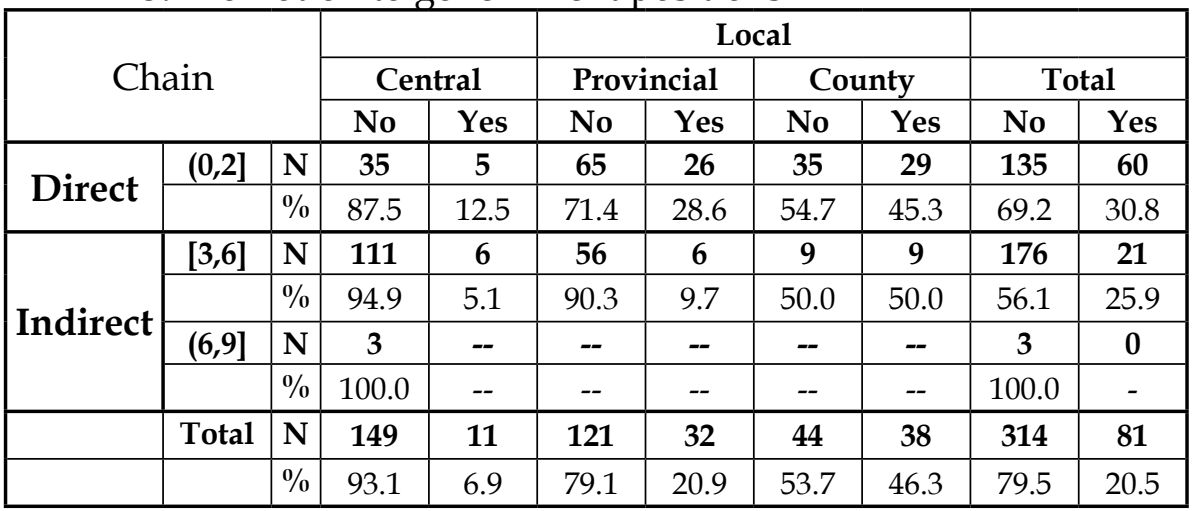

\section{Performance Versus Political Connections for Promotion}

We construct a logit model to explore the relationship between promotion prospects, company performance and the leader's political connections, while controlling for other relevant factors. We employ a logit model taking the form:

\section{Promotion $=\alpha_{0}+\alpha_{1}$ Perf $+\alpha_{2}$ Politician $+\alpha_{3}$ Edu $+\alpha_{4}$ Age $+\alpha_{5}$ Tenure $+\alpha_{6}$ Level $+\alpha_{7}$ Chain $+\alpha_{6}$ Size $+\alpha_{9}$ Monopoly $+\alpha_{10}$ Period 1 $+\alpha_{11}$ Perto $2+\mu$}

Where

Promotion (dummy) $-1=$ demotion, $0=$ transfer at level, $1=$ promotion.

Perf

Politician

Education

Age $^{19}$

Tenure $^{20}$ profit divided by total assets (\%) (dummy, avg 0.34) $1=$ leader has political or administrative experience, $0=$ otherwise. (dummy, avg 0.51) $1=$ leader has a masters' degree or $\mathrm{PhD}, 0=$ otherwise (range 29-69, average 48) number of years the leader served in current position, (average 4.21) 
Level

(dummy variable) $1=$ ultimate controller is SASAC at county-level or below, 2 = ultimate controller is provincial SASAC, $3=$ ultimate controller is central SASAC or central government agency

Chain

Size

distance from ultimate state controller (i.e. SASAC) (range 1-9)

the log of total assets of the firm

(dummy) 1 = industry has lowest market concentration when

Monopoly measured using Herfindahl-Hirschman Index (11.18\% of firms), 2 = industry has medium market concentration $(78.63 \%), 3=$ industry with highest market concentration $(10.19 \%)$

Period 1 and Period 2

(dummies) used for controlling the evaluation period set by SASAC. Period $1=1$ if year is 2003-2005, Period $2=1$ if year is 2006-2009.

We present the results in Table 6 . We find that administrative/political connections are associated with increased promotion prospects, but we do not find any significant effect for higher financial performance. Longer tenure and belonging to a central SOE group are associated with better promotion prospects, while age is a negative. In aggregate, this supports the proposition that political connectedness and patronage relationships, rather than financial performance, is important in SOE subsidiaries. However, breaking the group down into direct and indirect subsidiaries of central and local SOEs provides a richer story.

The 'central direct' group (column 2) includes the direct, listed subsidiaries of central SOEs, whose leadership was studied directly by Yang et al (2013). In contrast to their findings, we do not find any significant impact of performance, political connections or education in this group. The leader's length of tenure appears to be the only significant and positive predictor of promotion. At the highest level of directly controlled subsidiaries, there is another ' $X$ factor' - perhaps documented in their personnel dossier - that determines their promotion prospects.

The proposition that economic performance matters more as a factor for promotion at lower levels of government (Choi 2012; Landry, Lü \& Duan 2014) may apply to lower level subsidiaries of central SOEs (see column 2). Indeed, this is the only group of companies for which firm profitability and the leader's education credentials are positively and significantly associated with promotion. Surprisingly, administrative/ political connections appear to be a significant negative for this group. These 'central indirect' SOE subsidiaries are the most 'business like' of all the groups.

Subsidiaries of local SOEs, both direct (column 3) and indirect (column 4) do not reflect this logic. For both these groups, administrative/political connections appear significant, positive predictors of promotion. 
This may be because a greater proportion of promotions from local SOE subsidiaries are to government positions rather than to positions higher up the corporate pyramid.

TABLE 6. Promotion prospects for central $\mathrm{v}$ local, direct $\mathrm{v}$ indirect state-controlled leaders

\begin{tabular}{|c|c|c|c|c|c|}
\hline & (1) & (2) & (3) & (4) & (5) \\
\hline Dep. Var $=$ & \multicolumn{5}{|c|}{ Promotion $=-1$ (demotion), 0 at level, 1 promotion } \\
\hline & $\begin{array}{c}\text { full } \\
\text { sample }\end{array}$ & $\begin{array}{c}\text { central } \\
\text { direct }\end{array}$ & $\begin{array}{l}\text { central } \\
\text { indirect }\end{array}$ & $\begin{array}{l}\text { local } \\
\text { direct }\end{array}$ & $\begin{array}{c}\text { local } \\
\text { indirect }\end{array}$ \\
\hline \multirow[t]{2}{*}{ Perf } & 0.680 & 1.155 & $1.968^{* *}$ & -0.168 & 1.4 \\
\hline & $(1.25)$ & $(0.64)$ & $(1.96)$ & $(-0.18)$ & $(1.03)$ \\
\hline \multirow[t]{2}{*}{ Politician } & $0.206^{* *}$ & -0.322 & $-0.441^{* * *}$ & $0.482^{* * *}$ & $0.634^{* * *}$ \\
\hline & $(2.41)$ & $(-1.25)$ & $(-2.73)$ & (3.46) & $(3.22)$ \\
\hline \multirow[t]{2}{*}{ Edu } & 0.134 & 0.071 & $0.710^{* * *}$ & $-0.249^{*}$ & 0.399 ** \\
\hline & $(1.57)$ & $(0.25)$ & $(4.35)$ & $(-1.90)$ & $(2.01)$ \\
\hline \multirow[t]{2}{*}{ Age } & $-0.032^{* * *}$ & $-0.075^{* * *}$ & -0.0170 & $-0.040 * * *$ & -0.0130 \\
\hline & $(-4.37)$ & $(-3.18)$ & $(-1.13)$ & $(-3.72)$ & $(-0.72)$ \\
\hline \multirow[t]{2}{*}{ Tenure } & 0.039 ** & $0.236^{* * *}$ & -0.052 & $0.063^{* *}$ & 0.012 \\
\hline & $(2.10)$ & $(3.92)$ & $(-1.55)$ & $(2.23)$ & $(0.25)$ \\
\hline \multirow[t]{2}{*}{ Level } & $0.129^{* *}$ & & & & \\
\hline & $(2.17)$ & & & & \\
\hline \multirow[t]{2}{*}{ Size } & $0.075^{* *}$ & $0.185^{* *}$ & 0.0560 & 0.0670 & $0.153^{*}$ \\
\hline & $(2.44)$ & $(2.48)$ & $(0.91)$ & $(1.24)$ & $(1.78)$ \\
\hline \multirow[t]{2}{*}{ Mono } & 0.0820 & 0.118 & $-0.374^{* * *}$ & $0.298^{* \star}$ & $0.363^{*}$ \\
\hline & $(1.01)$ & $(0.31)$ & $(-2.59)$ & $(2.21)$ & $(1.80)$ \\
\hline \multirow[t]{2}{*}{ Chain } & 0.0360 & -- & $0.182^{* *}$ & -0.306 & 0.401 \\
\hline & $(0.76)$ & -- & $(2.14)$ & $(-1.08)$ & $(1.40)$ \\
\hline \multirow[t]{2}{*}{ period1 } & $0.204^{* *}$ & 0.488 & 0.158 & 0.186 & 0.307 \\
\hline & $(1.98)$ & $(1.44)$ & $(0.74)$ & $(1.21)$ & $(1.23)$ \\
\hline \multirow[t]{2}{*}{ period2 } & $0.223^{* *}$ & $0.625^{*}$ & -0.0860 & $0.462^{* * *}$ & 0.0820 \\
\hline & $(2.05)$ & $(1.78)$ & $(-0.39)$ & $(2.82)$ & $(0.32)$ \\
\hline \multirow[t]{2}{*}{ cut1_cons } & 0.0620 & 0.316 & -1.038 & -0.759 & $4.276^{*}$ \\
\hline & $(0.08)$ & $(0.16)$ & $(-0.70)$ & $(-0.55)$ & $(1.89)$ \\
\hline \multirow[t]{2}{*}{ cut2_cons } & $1.388^{*}$ & 2.154 & 0.687 & 0.367 & $5.546^{* *}$ \\
\hline & $(1.84)$ & (1.11) & $(0.47)$ & -0.27 & $(2.45)$ \\
\hline $\mathrm{N}$ & 2301 & 238 & 620 & 1008 & 435 \\
\hline Chi2 & $66.12^{* * *}$ & $32.4^{* * *}$ & $50.16^{* * *}$ & $36.23^{* * *}$ & $30.39^{* * *}$ \\
\hline
\end{tabular}

Notes: (1) ${ }^{* * *}, * *,{ }^{*}$ represents statistical significance at the $1 \%, 5 \%$ and $10 \%$ level, respectively; (2) $\mathrm{t}$-values are reported in parentheses. Unit is person-years. 
This appears to contradict the proposition that economic performance matters more at lower level of government, but it may in fact reflect a tighter connection between provincial governments and provincial SOEs than might exist between central government ministries and central SOEs. In the case that the local Party secretary is incentivized with economic performance, it could be that provincial SOEs are more likely to act as a policy arm of the province, possibly supporting particular projects or investments that is costly to the enterprise but has a spillover benefit to the province. Conversely, if they are big local employers or investors, then SOE connections to local governments could soften their budget constraint a little in the case of distress. This should reduce enterprise efficiency.

A common characteristic for both central and local 'direct' SOE groups is that age is a significant negative factor, and tenure is a significant positive factor affecting promotion. This likely reflects that leaders of these subsidiaries higher up the chain are likely to be older, and therefore facing retirement age. Neither age nor tenure are significant predictors of promotion for leaders of indirect SOEs.

\section{Conclusion: Drivers of or Obstacles to Reform?}

In this article we have developed the concept of an 'iron triangle' between the Chinese state, Party and business by mapping out some of the connections between state and business, and between business and Party. We have observed that leaders of state-owned enterprises and their publicly-listed subsidiaries form potential members of larger Partybased career structures. We conclude that SOEs leaders are well and truly part of the 'iron triangle', rather than professional business executives who just happen to be working for state-controlled enterprises. For this reason, we would expect them to act as obstacles to reforms that would separate business further from Party influence.

Leaders of SOEs do appear to be 'quasi officials', or at least 'state businessmen' rather than professional managers. In both SOEs and their publicly-listed subsidiaries, administrative experience or political connections appear to matter to get promotions. Based on new empirical analysis of leaders of listed SOEs, we show that more than a third have prior administrative experience or concurrent political roles. We find that almost one-fifth of leaders of county-level SOE subsidiaries, and almost one-tenth of leaders of provincial-level SOE subsidiaries, are promoted into government positions. We also observe that a leader of 
a listed SOE-subsidiary is twice as likely to retire as they are to enter private sector employment.

However, the governance structure does appear to make a difference. In the case of the subsidiaries of central SOE subsidiaries, we observe that leaders are promoted on the basis of financial performance. These are the largest, so offer the largest scope for promotion within a single conglomerate, as well as being amongst the most internationalized of SOEs. This stream feeds into the top leadership of central SOEs, which may be closer to the political rather than business realm.

One next step is to see whether these apparently different management incentives actually flow through to financial performance. Our findings would suggest that we should observe a difference in performance between subsidiaries of central and local SOEs. Other things being equal, the career incentives in favour of financial performance for distant subsidiaries of central SOEs should result in higher performance for them, relative to local SOE subsidiaries.

Kjeld Erik Brødsgaard is Professor at the Department of International Economics and Management and Director of China Policy Program, Copenhagen Business School.Email:keb.int@cbs.dk

Paul Hubbard is a Sir Roland Wilson PhD Candidate at the Crawford School of Public Policy, Australian National University. Email: paul.hubbard@anu. edu.au

Guilong Cai and Linlin Zhang (not attending) are both doctoral candidates in accounting at Sun Yat-sen Business School, Guangzhou, China.

\section{NOTES}

1 Thanks to Chris McNally and other participants at the 'China: Wealth and Power' conference, held at the Australian National University, 7-8 April 2016 for valuable comments and suggestions on an earlier draft of this article.

2 Communist Party of China 2013. 'Zhonggong zhongyang guanyu quanmian shenhua gaige ruogan zhongda wenti de jueding' ( Decision of the CPC Central Committee on Some Major Questions Concerning Comprehensively Deepening Reform). http://news.xinhuanet.com/politics/2013-11/15/c_118164235.htm. Accessed 12 June 2017.

3 According to Zhang Yi, former head of SASAC, central SOEs account for 70 per cent of Chinese non-financial investment abroad. http:/ / www.globaltimes.cn/content/927974.shtml

4 Cummine, Angela 2015. 'China's Sovereign Investment Funds in International 
Perspectives: The Exceptionalism of CIC and SAFE'. EABER Working Paper Series. http://www.eaber.org/sites/default/files/documents/EABER\%20Working\%20p aper\%20110\%20Cummine.pdf. (Accessed 12 June 2017).

5 Landry, Pierre F., Xiaobo Lü, and Haiyan Duan 2014. 'Does Performance Matter? Evaluating the Institution of Political Selection along the Chinese Administrative Ladder.' Forthcoming at Comparative Political Studies. Available at http:/ / papers. ssrn.com/sol3/papers.cfm?abstract_id=2452482. (Accessed 15 June 2016).

6 More details on official registration categories, and detailed statistics for industrialsector SOEs are presented in Hubbard (2016b).

7 Xinhua 2013. 'Full Text of Constitution of Communist Party of China.' Available at http://english.cpc.people.com.cn/206972/206981/8188095.html. (Accessed 15 June 2017).

8 Communist Party of China 2015. 'Zhonggong zhongyan, guowuyuan guanyu shenhua guoyou qiye gaige de zhidao yidian' (Guiding Opinions on Deepening the Reform of State-Owned Enterprises). http://www.gov.cn/zhengce/2015-09/13/ content_2930440.htm. (Accessed 12 June 2017).

9 See Zhonggong zhongyang bangongting (Office of the Central Committee) 2000. 'Shenhua ganbu renshi zhidu gaige gangyao' (The Plan for Deepening the Personnel Management System for Cadres). http:/ / cpc.people.com.cn/GB/64162/71380/71 382/71480/4854070.html.

10 Suo, Hanxue 2014. 'Guozi gaogan diaoyuan: chao 99\% bu yuan fangqi xingzheng jibie huan gao xin' (A Survey on SOE Heads: 99\% Unwilling to Give up Administrative Ranking for Higher Salary). Zhongguo Jingying Bao (China Business Journal), August 30. Available at http:// finance.sina.com.cn/china/20140830/003920165299.shtml. (Accessed 12 June 2017).

11 http://en.cosco.com/art/2013/4/15/art_765_35373.html

12 (that is, resources, manufacturing, and public utilities)

13 Rooker, Tyler 2016a. 'Zhongguo huagong jituan shangshi gongsi' (ChemChina Listed Companies). Rooker Consulting. http://www.rookerconsulting.com/china-consulting-weibo/chemchina-listed-companies. (Accessed 1 June 2016).

14 Rooker, Tyler 2016b. 'Bright Foods Group, Global Equity Structure - Rooker Consulting.' http://www.rookerconsulting.com/china-consulting-weibo/bright-foodsgroup-global-equity-structure. (Accessed 1 June 2016).

15 Xinhua 2012. 'Communist Party Expands Presence in Thriving Private Sector.' May 25. Available at http:/ / news.xinhuanet.com/english/china/2012-05/25/c_123187458. htm. (Accessed 1 June 2016).

16 Hawes, Colin 2007. 'Interpreting the PRC Company Law through the Lens of Chinese Political and Corporate Culture.' UNSW Law Journal 30 (3): 813-23. http:/ /www. unswlawjournal.unsw.edu.au/sites/default/files/47_hawes_2007.pdf. (Accessed 15 June 2017).

17 This coincides with the creation of SASAC in 2003, when the current system for appointing SOE leaders was introduced, and ends in end of the Hu Jintao administration in 2012. Companies that close or become wholly private owned in the period are excluded.

18 Zhongming, Cheng. 2010. 'Government Intervention, Pyramidal Structure and Investment of Local State-Owned Firms: Empirical Evidence From Chinese Capital Market.' IEE Xplore. Available at http://ieeexplore.ieee.org/document/5661174/ ?reload=true. (Accessed 15 June 2017).

19 Unlike Zhang et al (2015) we do not include an additional dummy variable for age exceeding 60 years. This provides a better fit for our model.

20 Unlike Zhang et al (2015) we do not include tenure squared as an additional con- 
trol. As Cao Zhunfang et al (2014) demonstrate, the leader's tenure and enterprise investment behaviour has a non-linear relationship (an invested $U$ shape). In order to avoid this correlation we omit tenure squared.

\section{REFERENCES}

Brandt, Loren, Johannes Van Biesebroeck, and Yifan Zhang 2014. 'Challenges of Working with the Chinese NBS Firm-Level Data.' China Economic Review 30: 339-52.

Brødsgaard, Kjeld Erik 2011. 'A Note on China's 12th Five-Year Plan: Content and Implications.' The Copenhagen Journal of Asian Studies 29 (2): 143-53.

Brødsgaard, Kjeld Erik 2012. 'Politics and Business Group Formation in China: The Party in Control?' The China Quarterly 211: 624-48.

Chen, Chih Jou Jay 2006. 'Elite Mobility in Post-Reform Rural China.' Issues and Studies 42 (2): 53-83.

Choi, Eun Kyong 2012. 'Patronage and Performance: Factors in the Political Mobility of Provincial Leaders in Post-Deng China.' The China Quarterly 212: 965-81.

Fan, Joseph P H, T. J. Wong, and Tianyu Zhang 2013. 'Institutions and Organizational Structure: The Case of State-Owned Corporate Pyramids.' Journal of Law, Economics, and Organization 29 (6): 1217-52.

Fu, Jenny 2013. 'The Governance of SOEs in China.' In Geoffrey Nicoll, Gerrard Brennan, and Jane Golley (eds.) The Australia-China Investment Relationship: Law, Governance and Policy. Canberra: Australian Centre on China in the World: 147-168.

Hubbard, Paul 2016a. 'Where Have China's State Monopolies Gone?' China Economic Journal 9 (1): 75-99.

Hubbard, Paul 2016b. 'Reconciling China's Official Statistics on State Ownership and Control.' EABER Working Paper Series. http:/ / www.eaber.org/node/25575.

Hubbard, Paul, and Patrick Williams 2016. 'Chinese State Owned Enterprises: An Observer's Guide.' International Journal of Public Policy forthcoming).

Kornai, Janos 1992. The Socialist System: The Political Economy of Communism / Janos Kornai. Princeton, N.J: Princeton University Press.

Kornai, János, Eric Maskin, and Gérald Roland 2013. 'Understanding the Soft Budget Constraint.' Journal of Economic Literature 41 (4): 1095-1136.

Landry, Pierre F. 2008. Decentralized Authoritarianism in China: The Communist Party's Control of Local Elites in the Post-Mao Era. Cambridge; New York: Cambridge University Press.

Lardy, Nicholas R. 2014. Markets over Mao: The Rise of Private Business in China. Washington, DC: Petersen Institute for International Economics.

Li, Hongbin, and Li An Zhou. 2005. 'Political Turnover and Economic Performance: The Incentive Role of Personnel Control in China.' Journal of Public Economics 89 (9-10): 1743-62.

Lin, Yifu (Justin), and Guofu Tan 1999. 'Policy Burdens , Accountability , and the Soft Budget Constraint.' American Economic Review, 89 (2): 426-31.

Naughton, Barry 1996. Growing out of the Plan: Chinese Economic Reform, 1978-1993. Cambridge: Cambridge University Press.

Shih, Victor, Christopher Adolph, and Mingxing Liu 2012. 'Getting Ahead in the Communist Party: Explaining the Advancement of Central Committee Members in China.' American Political Science Review 106 (01): 166-87.

Wu, Jinglian 2005. 'Reform of State-Owned Enterprises.' In Understanding and Interpreting Chinese Economic Reform. Mason, Ohio: Thomson South-Western: 139-176.

Yang, Ruilong Yang, Yuan Wang, and Huihua Nie. 2013. 'Zhun guanyuan de jinsheng 
jizhi: lai zi Zhongguo qiye de zhengju' (The Promotion System for Quasi-Government Officers: Evidence from Central State-Owned Enterprises in China). Management World 3: 23-33.

Yao, Yang 2016. 'An Anatomy of the Chinese Selectocracy.' Unpublished paper presented at the international conference 'China: Wealth and Power', Australian National University, Canberra, 7-8 April 2016.

Zhang, Jin 2004. Catch-up and Competitiveness in China: The Case of Large Firms in the Oil Industry. London: New York, N.Y.: RoutledgeCurzon.

Zhang, Linlin, Feng Liu, and Guilong Cai 2015. 'Jianguan duli xin, shichang hua jincheng yu guoqi gaoguan jinsheng jizhi de zhixing xiaoguo - jiyu 2003-2012 nian guoqi gaoguan zhiwei biangeng de shuju' (Regulatory Independence, Market-oriented Process and the Implementation Result of Executive Promotion System in the SOEs - Based on the SOE Executives Turnover data 2003-2012). Guanli shijie 10: 25-39. 